\title{
Quantitative analysis of fat, oil and grease in valikamam area, Sri Lanka and conversion of waste oil into grease
}

\author{
Kugamoorthy Velauthamurty ${ }^{1 *}$, Dilki Manisha Kurukulasuriya ${ }^{1}$ \\ ${ }^{1}$ Department of Chemistry, University of Jaffna, Sri Lanka \\ *Corresponding author E-mail: kvelauthamurty@yahoo.co.uk
}

\begin{abstract}
Groundwater is the main source of freshwater. Groundwater denotes to all the water occupying the voids, pores and fissures within geological formations, which originated from atmospheric precipitation either directly by rainfall infiltration or indirectly from rivers, lakes or canals. Groundwater pollution is a serious problem because many people depend on groundwater for their drinking water. Waste oil along with heavy metals is one of the major contaminant species makes water harmful. A one drop of heavy fuel oil is enough to contaminate a million gallons of freshwater. Waste oil is generated through dumping, land spreading, incineration, road oiling, industrial chemical spills, extensive use of pesticides, herbicides and fertilizers etc. For this study water samples were collected from forty of wells representing the Valikamam area. Then the water samples were analyzed for Fat, Oil and Grease using liquidliquid extraction with hexane and gravimetric determination. The results shows only four wells exceed the $10 \mathrm{mg} / \mathrm{L}$ while thirty six wells were potable. Waste oil disposal is a big threat these days around the world. Hence this paper gives a brief review about recycling waste oil by converting it into commercially important lubricating grease. Once the grease characterization is done for the grease obtained from waste oil, we can bring it up to the commercial stage on the other hand giving a better solution for the depletion of waste oil.
\end{abstract}

Keywords: Ground Water; Waste Oil; Recycling; Conversion; Grease; Heavy Fuel Oil.

\section{Introduction}

Industrialization has opened up a new era in agriculture, trade, transport and all other economic activities while proving the quality of man power. Rapid industrialization is a must in order to increase the national income of the country, to reduce the pressure of increasing population, to utilize the resources and so on. Most of industrial activities rely on various types of oils for their proper functioning.

Lubricants are widely used in manufacturing industries, power stations, automobiles, marine engines etc. Lubricants perform in the roles such as keep moving a part, reduce friction, transfer heat, transmit power, carry away contaminants and debris, protest against wear, prevent corrosion, seal for gases, prevent rust, and prevent internal combustion of engines in automotives. (Howard, 1998)

For automotive purpose people use engine oils, brake fluids, hydraulic fluids, gearbox fluids, automatic transmission fluid. For tractors Universal Tractor Transmission Oil (UTTO) and Super Tractor Oil Universal (STOU) are in use. For the other motors 2stroke engine oils, personal lubricants are in use. For industries air compressor oils, food grade lubricants, gas compressor oils, gear oils, bearing and circulating system oils, refrigerator compressor oils, steam and gas turbine oils are being used. Gas turbine engine oil and piston engine oil are used for the aviation. (Howard, 1998) Thus a huge range of oil types is being used widely and currently with the beginning of the industrial revolution.

After these lubricants are being used for a number of applications, the negative side that we all have to accept is either intentionally or accidentally we all are responsible for piling up tons of dump oil to our precious nature. Even if we apply good lubricant initially, after passing through heavy machinery, it will enrich with many hazardous constituents as most of industries get waste oil as a byproduct.

Directly or indirectly a large quantity of waste oil is cumulating in our ecosystem daily. When these lubricants reach into the soil, it will deposit along with organic compounds like biphenyl, petrochemicals, and phenolic compounds and heavy metals like chromium, copper, lead, manganese, nickel, and zinc. A heavy metal refers to a metallic element which has a relatively high density and is toxic or poisonous even at low concentration. If any by chance this hazardous waste oil is mixed up with ground water source either by deposition, sedimentation, penetration through fissure or flowing with water, the consequences will be unimaginable. (Clesceri, 1998)

When the soil and ground water get polluted in agricultural area, the heavy metals that absorbed by plants and algae ultimately accumulate in their tissues. Animals that graze on those contaminated plants and drink polluted water, as well as marine lives that breed in heavy metal polluted water also aggregate such metal in their tissues and milk. The European union informs a standard of $0.3 \mathrm{mg} / \mathrm{g}$ for mercury. Sweden initially introduced a limit of 0.5 $\mathrm{mg} / \mathrm{g}$ but discovered that most of the fish from the Baltic and inland lakes already exceeded this, so were forced to increase the limit to $1.0 \mathrm{mg} / \mathrm{g}$. They advised the public not to eat more than two fish meals per week. (Clesceri, 1998)

At last humans who exposed to heavy metals by consuming contaminated plants and animals will experience various biochemical disorders such as gastrointestinal disorders, diarrhea, tremor, sto- 
matitis, hemoglobinuria, ataxia, paralysis, vomiting, convulsion, depression, pneumonia, dysfunction in kidneys, joints, reproductive system, cardiovascular system, damage in central nervous system and neurotoxic, carcinogenic, mutagenic disorders. Our group mainly tried to figure out that minimizing this oil contamination problem. Instead of discarding waste oil directly into the environment we collect waste oil and recycle it producing lubricating grease. (Reuter, 1998)

Grease is a semi solid lubricant. It generally consists of soap emulsified with mineral or oil. The function of grease is to remain it contact with and lubricate moving surfaces without leaking out under the force of gravity, centrifugal action or being squeezed out under the pressure. The properties of grease are based on the amount and type of thickener used. Currently many researches were conducted to explore alternative sources for grease production due to increasing of crude oil prices in the world market and the depletion of source. So the success of this research will not only reduce the oil pollution but also produce grease at low cost. Main components of lubricating grease are base oil (70-95\%), thickener (3-30\%) and additives (0.1-10\%). Here the waste oil we are going to use act as the base oil once it removes all the heavy metal ions. Making grease is similar to making soap. Both products rely on a chemical reaction to take place between oil, fat or fatty acids (base oil) and alkali base material (thickener) to form soap like materials. Grease uses a variety of metal hydroxide alkaline to make and define grease type. For instance aluminum hydroxide makes aluminum grease, lithium hydroxide makes lithium grease and calcium hydroxide makes calcium grease.

Chemical reaction used in here known as "saponification reaction". Fats and oils are composed of triglycerides. Three fatty acid molecules attached to a glycerol molecule. In waste oil, some of the glycerides have broken down so that the fatty acids are separated from the glycerol molecule and these are called free fatty acids. These free fatty acids tend to react with alkali catalyst and thus reduce the speed of the trans-esterification reaction.

Greases are manufactured in variety of consistencies using the number rating system of National Lubricating Grease Institute (NLGI). There are so many tests that run to characterize the quality of grease. Some grease tests are cone penetration test, moisture content test, density test, viscosity, Dropping point test, Copper corrosion test, oxidation stability test along the colour, appearance, soap thickeners, additives, plumbability, slumpability, operating temperature and water resistance. Once the grease formation is done it should be tested for all these parameters in order to produce commercial grease.

Among a wide range of waste lubricants, we selected waste Heavy Fuel Oil (HFO) to produce grease. HFO is an important resource and a petroleum base product. It is a black liquid oil with higher viscous, specific gravity and heavier molecular composition. It is a residue deriving from crude oil refining. Heavy fuel oils are used in medium to large industrial plants, furnaces, marine applications (ships, locomotives) domestic heaters and power stations in combustion equipment such as boilers, furnaces and diesel engines. HFO burnt in a furnace or boiler is for generation of heat or used in an engine for the generation of power. And also, to meet the needs of the electricity production in industries, manufacturing and power stations. Reasons for wide range of using HFO are: less consumption, less cost, low maintenance cost, complete combustion, improved efficiency of boilers, ovens and engines, fully cus- tomizable applications, safety and performance and high functionality.

\section{Materials and methods}

\subsection{Sampling plan}

Water samples were collected from wells around Chunnakam power plant area according to a systematic sampling plan. Wells for sampling were selected along eight directions namely North $(\mathrm{N})$, Northeast (NE), East (E), Southeast (SE), South (S), Southwest (SW), West (W), and Northwest (NW). Along each direction, wells were selected on or near the grid points of 200 meter interval up to $1 \mathrm{~km}$. Hence 40 wells were selected as we mentioned in our previous work. (Velauthamurty.K, 2016)

\subsection{Collection of water samples}

Grab sampling method was used to collect the water samples. Approximately $1500 \mathrm{ml}$ water samples was collected into glass bottles and each sample was preserved with $5 \mathrm{ml}$ of 1: $1 \mathrm{HCl}$. Water samples were collected from the surface and bottom of the dug wells. In the case of tube well only one sample is collected. Ruttner water sampler was used for the water sample collection in our analysis. Samples were collected by direct pumping in tube wells. (Velauthamurty.K, 2016) forty water samples were collected during the period of January 2016 to March 2016

\subsection{Determination of fat, oil, grease in ground water}

All forty samples were subjected into liquid-liquid extraction with hexane and gravimetric determination which is an effective analytical method to detect fat, oil, and grease in water. Experiments were conducted in the inorganic laboratory in Department of Chemistry, University of Jaffna.

\subsection{Analytical procedure used for determination of FOG}

Initially all the samples were acidified by $\mathrm{HCl}(\mathrm{pH}=2)$ samples were sequentially extracted three times using hexane, shaken vigorously for ten minutes per extraction. The ratio of solvent to sample should be no less than 1:20. The solvent extracts are drop wisely passed through a drying funnel containing anhydrous sodium sulfate. Distillation was done to acquire hydrocarbon residue. It was put into oven and set temperature as $70{ }^{\circ} \mathrm{C}$ then put into desiccator for cooling. Determination of the residue was done by analytical electronic balance. (Vogel Arthur, 1961 and Olumuyiwa, 2012)

\section{Results and discussion}

FOG content was calculated using following equation.

FOG content in $\mathrm{mg} / \mathrm{L}=$ (weight of FOG $/ 300 \mathrm{ml}$ ) $* 10^{6}$

FOG content of water samples that we collected in 2016 is compared with the FOG content of water samples which collected in same locations in 2015. (Velauthamurty.K, 2016)

Table 1: FOG Content 2015 vs. 2016 Variation of FOG Content in Ground Water from 2015 to 2016.

\begin{tabular}{llll}
\hline No & Sample Number & Final results of Fat, Oil, Grease in mg/l & 2016 \\
\hline 1 & N1 & 2015 & 2.33 \\
2 & N2 & Not detected & 6.82 \\
3 & N3 & 7.26 & 4.57 \\
4 & N4 & 4.62 & Not detected \\
5 & NE1 & Not detected & 2.56 \\
6 & NE2 & Not detected & 10.56 \\
7 & NE3 & 10.56 & Not detected \\
8 & NE4 & Not detected & Not detected \\
9 & & 12.54 & Not detected \\
\hline
\end{tabular}




\begin{tabular}{|c|c|c|c|}
\hline 10 & NE5 & Not detected & Not detected \\
\hline 11 & E1 & Not detected & 3.78 \\
\hline 12 & E2 & 5.28 & 74.8 \\
\hline 13 & E3 & 10.56 & 9.8 \\
\hline 14 & E4 & Not detected & Not detected \\
\hline 15 & E5 & Not detected & 5.68 \\
\hline 16 & SE1 & Not detected & 3.96 \\
\hline 17 & SE2 & 9.99 & 7.85 \\
\hline 18 & SE3 & Not detected & 4.55 \\
\hline 20 & SE5 & Not detected & Not detected \\
\hline 21 & $\mathrm{~S} 1$ & Not detected & 2.88 \\
\hline 22 & $\mathrm{~S} 2$ & 4.95 & 6.92 \\
\hline 23 & S3 & 8.58 & 4.56 \\
\hline 24 & $\mathrm{~S} 4$ & Not detected & 8.47 \\
\hline 25 & S5 & Not detected & Not detected \\
\hline 26 & SW1 & 3.96 & 4.56 \\
\hline 27 & SW2 & 3.96 & 3.63 \\
\hline 29 & SW4 & Not detected & Not detected \\
\hline 30 & SW5 & Not detected & Not detected \\
\hline 31 & W1 & 3.33 & 4.95 \\
\hline 32 & W2 & 13.53 & 7.53 \\
\hline 33 & W3 & Not detected & 3.41 \\
\hline 34 & W4 & Not detected & 6.97 \\
\hline 35 & W5 & Not detected & 3.95 \\
\hline 36 & NW1 & 9.24 & 10.56 \\
\hline 37 & NW2 & 8.25 & 10.89 \\
\hline 38 & NW3 & 1.65 & Not detected \\
\hline 39 & NW4 & Not detected & Not detected \\
\hline 40 & NW5 & Not detected & 12.54 \\
\hline
\end{tabular}

\section{- FOG content in 2015}

Variation of FOG content in ground water from 2015 to 2016
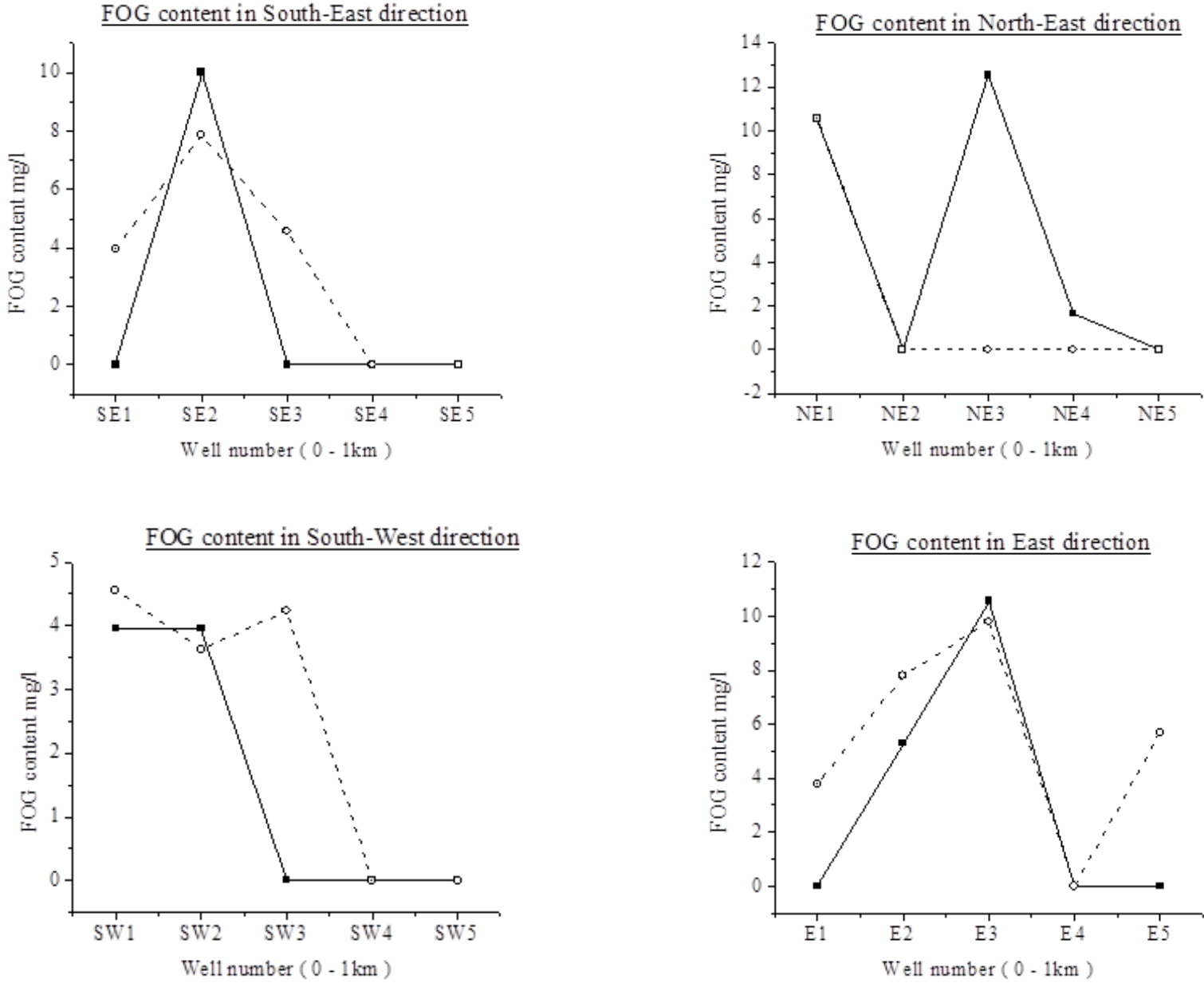

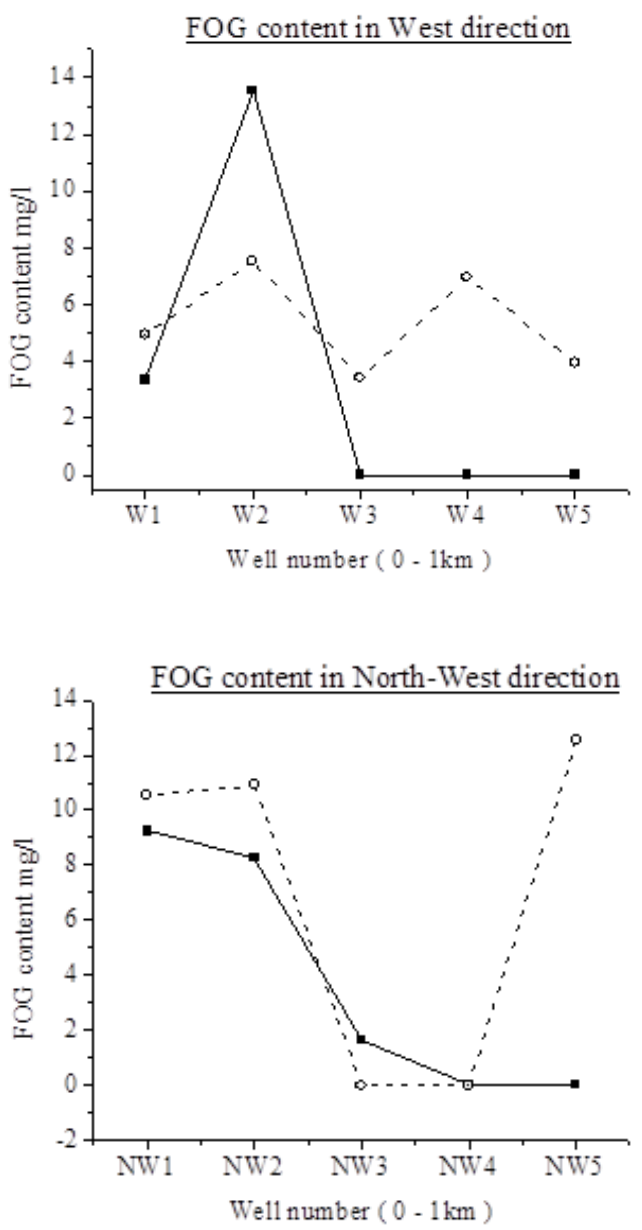

According to the results in 2016, only four wells exceeded the 10 $\mathrm{mg} / \mathrm{l}$ and three of them were taking from NW direction wells. Twenty three samples were in the range of 2-10 mg/l, while thirteen wells revealed without FOG. When compare with data from 2015, FOG value has been rapidly increased in the S4, SW3, NW5 wells in high amount, while NE3 well unrevealed any FOG. So the risk of consuming well water in NE3 directed well has been totally removed by 2016. (Velauthamurty.K, 2016)

The variation of FOG is due to several factors like population density, closeness to the power station, agricultural activities, cultivated lands, abandoned wells, microbial activity, weather, salinity and geological conditions like slope, soil type, pores, fissures, minerals.

Valikamam is an intensive agricultural area with a dense population. Ground water here is always exposed to continuous supply of agrochemicals, alcoholic beverages, fertilizers, pesticide, weedicide, glyphosate (Round up, chelates, heavy metals), oil hydrocarbons, lubricants which gradually create a toxic environment. As a result of flowing of heavy metals and FOG it will sustain in our food chain, food web system and end up with a big havoc.

Abandoned wells contain high number of microbes as it is not used by humans regularly. Hence many secretions excluded by fungi, bacteria, Cyanobacteria and algae will also deteriorate the well water system.

It is advisable to held awareness programs for farmers, students, villagers about ground water pollution. Frequent usage is also a good habit to renew and refresh the well water system. And also introducing environment friendly natural organic fertilizers is also much appreciable. (Irwin, 1997 and Adewuyi, 2012)

\subsection{Conversion of waste HFO into lubricating grease}

The waste HFO was collected from some power plant in the middle of Jaffna peninsula. $100 \mathrm{ml}$ of waste $\mathrm{HFO}$ was added into a beaker and heated to reach $120^{\circ} \mathrm{C}$ to remove the remaining water
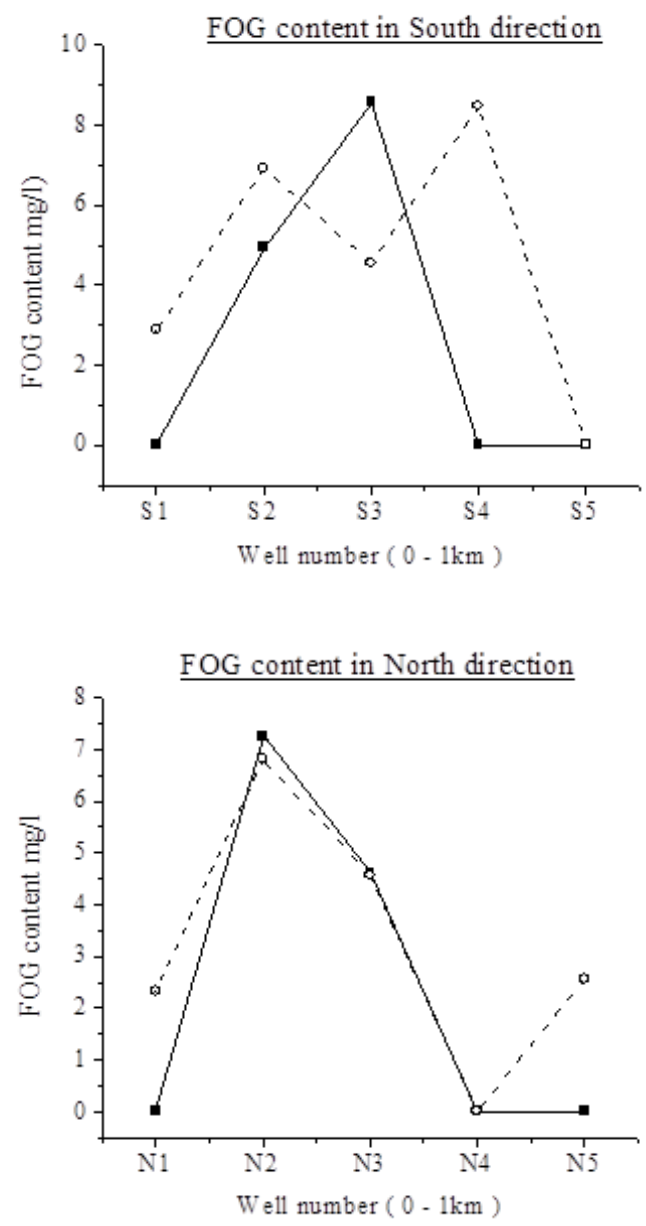

and volatile particles. This oil was allowed to cool down to room temperature. $2 \mathrm{ml}$ of acetic acid was added and stirred at 100 r.p.m. $0.1 \mathrm{ml}$ of $\mathrm{H}_{2} \mathrm{O}_{2}$ was added in order to oxidise lead into lead (11). This reaction continued for 30 minutes. (Daniel Solomon et.al, 2010)

Then the system was allowed to sedimentation for five hours. Next the oil layer on the top of the sludge was separated. This separated oil can use as the base oil and it is metal free. $65 \mathrm{ml}$ of this base oil is mixed with $35 \mathrm{ml}$ of cooking oil, $5 \mathrm{~g}$ of $\mathrm{NaOH}$ and $2 \mathrm{~g}$ of $\mathrm{Ca}(\mathrm{OH})_{2}$ which were made as a aqueous solution by adding $10 \mathrm{ml}$ of water. All the reagents were mixed vigorously.

The temperature was increased to $150^{\circ} \mathrm{C}$. From this point saponification started. Then gradually temperature was increased into $225^{\circ} \mathrm{C}$. Finally it was allowed to cool to room temperature while stirring. (Sangar.S, 2016) After cooling the grease was formed as appeared in the Fig.1.
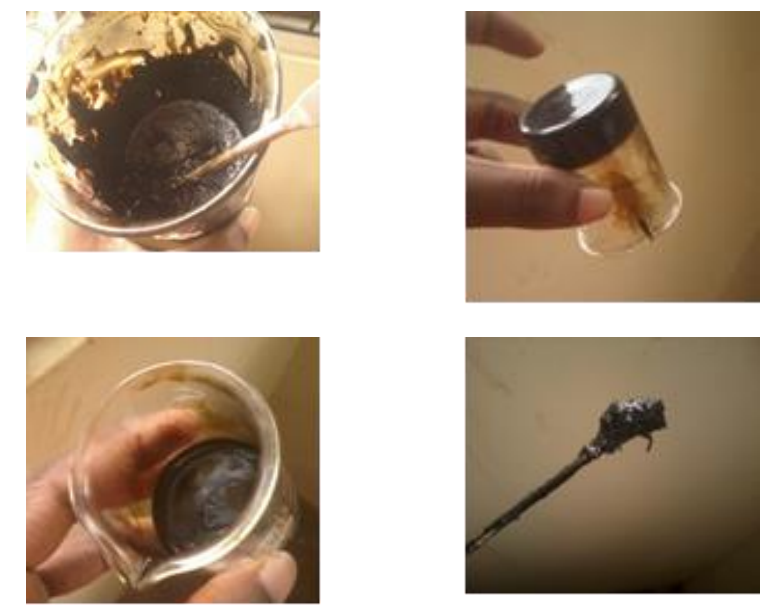

Fig. 1: Produced Grease In Lab. 


\subsection{Discussion}

Waste HFO is comprised of heavy metals like chromium, copper, lead, manganese, nickel, zinc. Even it has a high-energy value. The combustion is also not favorable as it can cause air pollution. So, recycling process will be more advisable.

Acetic acid is the chemical treatment that is used in our procedure to demetallize the waste HFO. It has a potential to precipitate al the present heavy metals as its acetates. They are $\mathrm{Pb}\left(\mathrm{CH}_{3} \mathrm{COO}\right)_{2}$, $\mathrm{Cr}_{3}(\mathrm{OH})_{2}\left(\mathrm{CH}_{3} \mathrm{COO}\right)_{2}, \quad \mathrm{Cu}\left(\mathrm{CH}_{3} \mathrm{COO}\right)_{2}, \quad \mathrm{Zn}\left(\mathrm{CH}_{3} \mathrm{COO}\right)_{2}$, $\mathrm{Mn}\left(\mathrm{CH}_{3} \mathrm{COO}\right)_{2}, \mathrm{Ni}\left(\mathrm{CH}_{3} \mathrm{COO}\right)_{2}$ sludge in the bottom layer contains the heavy metal precipitates. After the separating of the base oil from the acetic acid treatment we can conduct furthermore tests to analyze the bottom sludge layer containing heavy metal precipitates. But it is worthy to analyze this sludge part after the different amount of acetic acid treatment and optimize the amount of acetic acid which precipitate high amount of heavy metals. Further we suggested to conduct these chemical tests to conduct for water after mixing up with sludge.

$\mathrm{Pb}$ - Lead is precipitated as the chromate with $\mathrm{K}_{2} \mathrm{CrO}_{4}$ in medium buffered with acetic acid and ammonium acetate. The precipitate is washed with water, dissolved in dilute $\mathrm{HCl}$, treated with $\mathrm{KI}$ solution and liberated $\mathrm{I}_{2}$ titrate with a standard solution of $\mathrm{Na}_{2} \mathrm{~S}_{2} \mathrm{O}_{3}$.

$\mathrm{Pb}\left(\mathrm{C}_{2} \mathrm{H}_{3} \mathrm{O}_{2}\right)_{2}+\mathrm{K}_{2} \mathrm{CrO}_{4}---------->\mathrm{PbCrO}_{4}+2 \mathrm{KC}_{2} \mathrm{H}_{3} \mathrm{O}_{2}$

$\mathrm{PbCrO}_{4}+2 \mathrm{HCl}----------->\mathrm{H} 2$

$\mathrm{CrO}_{4}+\mathrm{PbCl}_{2}$

$\mathrm{H}_{2} \mathrm{CrO}_{4}+6 \mathrm{KI}+12 \mathrm{HCl}---------->2 \mathrm{CrCl}_{3}+6 \mathrm{KCl}+3 \mathrm{I}_{2}+8 \mathrm{H}_{2} \mathrm{O}$

$\mathrm{Cu}$ - Copper can be analyzed by electrolytic determination in the presence of sulphuric acid.

Cathode $-\mathrm{Cu}^{2+}+2 \mathrm{e}------->\mathrm{Cu}$ Anode - 2, $\mathrm{OH}^{-}------>>1 / 2 \mathrm{O}_{2}+$ $\mathrm{H}_{2} \mathrm{O}+2 \mathrm{e}$

$2 \mathrm{H}^{+}+2 \mathrm{e}-------->\mathrm{H}_{2}$

$\mathrm{Ni}$ - Nickel is precipitated by the addition of an alcoholic solution of dimethylglyoxime (H.Dmg) to a hot slightly acidic solution of the nickel compound and then adding a slight excess of $\mathrm{NH}_{3}$ solution. The precipitate is washed and weighed as nickel dimethylglyoxime after drying at $100^{\circ} \mathrm{C}-120^{\circ} \mathrm{C}$.

$\mathrm{Ni}^{2+}+2 \mathrm{HDmg}--------->\mathrm{Ni}(\mathrm{Dmg})_{2}+\mathrm{H}_{2} \mathrm{SO}_{4}$

$\mathrm{Cr}-$ Chromic salts are oxidized into dichromates by boiling with excess of persulfate solution in the presence of a little $\mathrm{AgNO}_{3}$. The excess of persulfate remaining after the oxidation is complete ic destroyed by boiling the solution for a short time. The dichromate content of the resultant solution is determined by the addition of excess of standard ferrous solution and titration of the excess of latter with standard $0.1 \mathrm{~N} \mathrm{~K}_{2} \mathrm{Cr}_{2} \mathrm{O}_{7}$. (Daniel Solomon et.al, 2010 and Sangar.S, 2016)

\section{Conclusion}

In the case of grease production, acetic acid treatment is more beneficial for the demetallization process as its' less cost, mild condition, easiness to handle, availability, efficient precipitation of heavy metals. Only minute amount requires to demetallize a considerable amount of waste HFO. If there is an intention to bring it upto commercial stage more grease tests and quality parameters have to be carried out in future.

Among the several ground water quality parameters, Fat Oil Grease takes a significant place as it carries a bulk of heavy metals along with it. In order to minimize the FOG content we have to confine a wide range of oil hydrocarbons used fertilizers, mineral oil, soap, detergents, chemical sprays, petroleum products, waste oil etc. Once groundwater becomes contaminated it is really difficult and expensive to clean up and reinstate it.

\section{Acknowledgement}

KV like to thank Head/Department of Chemistry for granting permission to conduct this research work and Mr.A.Thabesan (Technical officer, Department of Chemistry, University of Jaffna, Sri Lanka) for all the technical assistance during the research in the Department of Chemistry, University of Jaffna, Sri Lanka.

\section{References}

[1] Howard, Alan G., Aquatic Environmental Chemistry, Oxford University Press, Oxford, UK, 1998.

[2] Clesceri, Lenore S., Arnold E. Greenberg, and Andrew D. Eaton, Standard Methods for the Examination of Water and Wastewater, 20th ed., American Public Health Association, Washington, D.C., 1998.

[3] Reuter, John E., Brant C. Allen, Robert C. Richards, James F. Pankow, Charles R. Goldman, Roger L. Scholl, and J. Scott Seyfried, "Concentrations, Sources, and Fate of the Gasoline Oxygenate Methyl tert-Butyl Ether (MTBE) in a Multiple-Use Lake," Environmental Science and Technology, 1998, 32, 3666-3672. https://doi.org/10.1021/es9805223.

[4] Vogel Arthur1; "A text book of quantitative inorganic analysis including elementary instrumental analysis", Longman group limited, London, $3^{\text {rd }}$ edition, 1961.

[5] Olumuyiwa I. Ojo, Fred A.O. Otieno, George M. Ochieng. Groundwater: Characteristics, qualities, pollutions and treatments: An overview. International Journal of Water Resources and Environmental Engineering Vol. 4(6), pp. 162-170, June 2012

[6] Kugamoorthy Velauthamurty. Quantitative analysis of Fat, oil and grease in Groundwater of Valikamam area, Sri Lanka. Der Pharmacia Lettre, 2016, 8 (4):225-232.

[7] Irwin.R.J.M., Vanmouswerik, Steven.L, Scese.M.D., Basham.W., Encylopedia,

[8] National Park Service, Water resources division, Fortcolins, Colarado, 17, 1997.

[9] Adewuyi,G.O., and Olowu.R. A., 2012, Assessment of oil and grease, total petroleum hydrocarbons and some heavy metals in surface and groundwater within the vicinity of NNPC oil depot in Apata, Ibadan metropolis, Nigeria.

[10] Daniel Solomon et.al, 2010, A new approach to the determination of oil and grease in water and wastes.

[11] Sangar.S, Velauthmurty.K, Hamsathvanie.K, Conversion of used heavy fuel oil and lubricant engine oil mixer into lubricating grease, Proceedings of Annual Research Sessions, University of Peradeniya, Sri Lanka, 2015, Vol 19, 101 